- Rose, I. A., and O'Connell, E. L., J. Biol. Chem., 244, 6548 (1969).

'Offord, R. E., Nature, 211, 591 (1966).

' Waley, S. G., MacGregor, J. C., Rose, I. A., and O'Connell, E. L., Nature 227,181 (1970) (following article).

\section{Identification of Site in Triose Phosphate Isomerase labelled by Glycidol Phosphate}

GLYCIDOL (2,3-epoxypropanol) phosphate inactivates and becomes covalently bound to triose phosphate isomerase (EC 5.3.1.1; TIM); the kinetics and stoichiometry of the reaction, and the structure of the reagent, indicate a specific reaction at the active centre of the enzyme ${ }^{1}$. The site that is labelled by this inhibitor, and by glycidol in the presence of inorganic phosphate, has now been identified. Iodohydroxyacetone phosphate ${ }^{2}$ and bromohydroxyacetone phosphate ${ }^{3}$ are also specific inhibitors of TIM. The amino-acid sequence round the site in chicken muscle TIM labelled by the bromo compound has been established ${ }^{4}$; we were greatly helped by knowing the sequence of their peptide.

Rabbit muscle TIM (Boehringer, London) was inactivated with $(+,-)$-glycidol ${ }^{32} \mathrm{P}$-phosphate (4 mM, 5.75 $\times$ $10^{6}$ c.p.m./umole) (ref. 1; experiment 2 of Table 1). The digest obtained by treatment of the TIM with onefiftieth of its weight of pepsin for $22 \mathrm{~h}$ in 5 per cent formic asid was fractionated on 'Sephadex G-25' in 0.5 per cent formic acid. The radioactive peptide was further purified by paper electrophoresis at $p H \mathbf{H} 1.9$ and then at $p H \mathbf{H} .5$; the phosphoric acid group (in contradistinction to the carboxyl group of peptides) is still largely ionized at, $p \mathrm{H} 1.9$ and the radioactive peptide was uncharged. The amino-acid composition expressed as a molar ratio was: $\mathrm{Glu}_{0.99} \mathrm{Pro}_{1 \cdot 12} \mathrm{Ala}_{0.91} \mathrm{Val}_{1 \cdot 05} \mathrm{Tyr}_{0 \cdot 93}$; tryptophan was present. One mole of peptide contained 1.03 mole of ${ }^{32} \mathrm{P}$. Subsequently, this peptide (Pl*) was obtained from TIM treated with non-radioactive glycidol phosphate; the yield was 37 per cent. The amino-acid composition (expressed as a molar ratio) of the acid hydrolysate was Glu $_{1.05} \mathrm{PrO}_{0.98} \mathrm{Ala}_{0.96} \mathrm{Val}_{1.06} \mathrm{Tyr}_{0.95}$; the amino-acid composition of an enzymic (aminopeptidase $M$ ) digest was: $\mathrm{Ala}_{1 \cdot 00} \mathrm{Val}_{1 \cdot 03} \mathrm{Tyr}_{1 \cdot 14} \operatorname{Trp}_{0 \cdot 82}$. The absence of proline and the amino-acid preceding it from aminopeptidase $\mathbf{M}$ digests has been observed on several occasions ${ }^{5,6}$. The corresponding peptide $(\mathrm{Pl})$ was also isolated from a peptic digest of native TIM ; the peptide is present in the last peak that has appreciable amounts of material absorbing at $280 \mathrm{~nm}$ and it characteristically contains both tyrosine and tryptophan.

In the labelled peptide $\left.(\mathrm{Pl})^{*}\right)$ one of the amino-acids is combined with the moiety from glycerophosphoric acid, and the main question is whether the compound is an ether derived from tyrosine or an ester derived from ghutamic acid. The labelled peptide $\mathrm{Pl}^{*}$ gave an immediate Pauly reaction at $p \mathbf{H} \mathbf{9 \cdot 5}$ which suggests that the phenolic $\mathbf{O H}$ is free. (The electrophoretic mobility $(m)$ at $p H \mathbf{H} \cdot 5$ was $0 \cdot 27$; the values of $m$ refer to anionic mobilities at $p H 6.5$ after electrophoresis at $50 \mathrm{~V} / \mathrm{cm}$ in a Camag cooled plate apparatus and wero calculated as described by Offord ${ }^{7}$.) The unlabelled peptide Pl has $m=0.21$. These values of $m$ are consistent with $\mathrm{Pl}^{*}$ having a charge between -1 and -2 ; that is, with its being an ester, not an ether. Furthe: evidence was obtained by treatment of $\mathrm{Pl}^{*}$ (80 nmole) with $1 \mu \mathrm{g}$ of phosphatase (potato acid phosphatase, Boehringer, London) at $p \mathbf{H} \mathbf{5 \cdot 6}$ for $\mathbf{I} \mathbf{h}$. The dephosphorylated peptide, after desalting on 'Sephadex $G-10$ ', had zero mobility at $p H \mathbf{H} \cdot 5$. After alkaline hydrolysis ( $1 \mathrm{M}$ ammonia solution for $16 \mathrm{~h}$ at room temperature), the mobility of the peptide increased to $0 \cdot 21$.

Clearly it is the glutamic acid residue in the isolated peptide that is labelled. Because we have no evidence that the label migrates, we believe that this glutamic residue in TIM reacts with glycidol phosphate. The lability of the

labelled protein towards alkali ${ }^{1}$ is consistent with this view. The reaction seems to be specific: a peptide "map" of a tryptic digest of the labelled enzyme revealed only one radioactive spot, which coincided with one of the Ehrlich-positive spots.

The amino-acid sequence of $\mathrm{Pl} *$ and $\mathrm{Pl}$, derived by the "dansyl"-Edman method ${ }^{8}$ supplemented by the use of carboxypeptidase $A$ and by cleavage with N-bromcsuccinimide ${ }^{9}$, was: Ala-Tyr-Glu-Pro-Val-Trp.

Unpublished experiments have shown that TIM is inactivated by $(+,-)$-glycidol if inorganic phosphate is also present; the rate is half the maximum when the concentration of phosphate is $4 \mathrm{mM}$, a value comparable with that for the inhibition constant in the enzymic reaction ${ }^{10}$. DL-Glycerophosphate protects the TIM. as it does in the reaction with glycidol phosphate'.

The site labelled by glycidol was investigated by treating rabbit muscle TIM (1 $\mathrm{mg} / \mathrm{ml}$.) with $0.27 \mathrm{M}$ glycidol in $20 \mathrm{mM}$ potassium phosphate at $p \mathrm{H} 7.5$ for $6 \mathrm{~h}$ at $37^{\circ} \mathrm{C}$ : the extent of inactivation (compared with a control that lacked glycidol) was about 60 per cent. When the protein was treated as described, the peptide containing tyrosine and tryptophan was obtained in two forms. One form was acidic $(m=0.21)$ : this is the unlabelled peptide $\mathrm{Pl}$. The other form was neutral at $p H \mathbf{H} .5$ but was converted into Pl by treatment with $1 \mathrm{M}$ ammonia solution for $24 \mathrm{~h}$ at room temperature. The amino-acid composition of the neutral peptide was: Glu $_{1 \cdot 36} \mathrm{Pro}_{0 \cdot 95} \mathrm{Ala}_{1 \cdot 05} \mathrm{Val}_{1 \cdot 0} \mathrm{Tyr}_{0 \cdot 5}$; tryptophan was present. The hydrolysate of the peptide contained glycerol : 5.2 nmole gave $8.8 \mathrm{nmole}$ of glycerol; the enzyme assay ${ }^{11}$ is not very precise when such small amounts of material are used. Thus the neutral form is the glyceryl ester of peptide $P 1$, and the reaction with glycidol occurs at the same site as the reaction with glycidol phosphate. We attribute inactivation of the enzyme by glycidol to reaction at this site, but do not know whether other sites also react.

The uniquely reactive glutamate residue in TIM may well be responsible for the key step in the enzyme's action, namely, the removal of a proton from $\mathrm{Cl}$ of dihydroxrace. tone phosphate or C2 of glyceraldehyde phosphate ${ }^{12}$ : earlier work $^{13}$ suggested that a histidine rosidue might play this part.

We thank the Medical Research Council and the US Public Health Service for financial support.

Note added in proof. The sequence of the recently reported (F. C. Hartmann, Biochem. Biophys. Res. C'rm. mun., 39, 384; 1970) active-site tryptic peptide is consist. ent with our results except for the position of the second alanine residue.

S. G. WATEY*

$$
\text { Janet C. Miller }
$$

Nuffield Laboratory of Ophthalmology,

University of Oxford.

\section{A. Rose}

E. L. O'CONNELL

Institute for Cancer Research,

Philadelphia, Pennsylvania.

Received March 20, 1970.

* Present address: Sir William Dum School of Pathology, University of Oxford, Oxford OXi 3RE.

1 Rose, I. A, and O'Connell, E. I. J Biol. Chem, 244, 6548 (1969).

3 Hartman, F. C., Biochem. Biophys. Res. Commun., 38, 888 (1968).

${ }^{3}$ Coulson, A. F. W., Knowles, J. R., and Offord, R. E., Chem. Commun., 7 (1970).

${ }^{4}$ Coulson, A. F. W. Knowles, J. R., Priddle, J. D., and Offord, R. F. Nature, 22\%, 180 (1970) (preceding article).

s Takahashi, K., Stein, W. H., and Moore, S., J. Biol. Chem., 242, 4682 (196') - Plummer, T. H., J. Biol. Chem., 244, 5246 (1969).

7 Offord, R. E., Nature, 211, 591 (1966).

8 Gray, W. R., in Methods in Enzymology (edit. by Hirs, C. H. W.), 11. 46 (Academic Press, New York, 1967).

Ramachandran, L. K, and Witkop, B., in Methods in Enzymology (edit. by Hirs, C. H. W.). il, 283 (Academic Press, New York, 1967)

10 Burton, P. M., and Waley, S. G., Biochim. Biophys. Acta, 151, 714 (1968).

11 Wurton, P. M., and Waley, S. G., Biochim. Biophys. Acta, 151, 714 (1968). ieland, O., in Methods of Enzymatic A nalysi

Rose, I. A., Brookhaven Symp. Biol., 15, 293 (1962).

13 Burton, P. M., and Waley, S. G., Biochem. J., 100, 702 (1966), 